\title{
Assessment of Cytotoxicity and Genotoxicity Potential of Effluents from Bahir Dar Tannery Using Allium cepa
}

\author{
Tayachew Admas $\mathbb{D}^{1}$ and Bizuayehu Kerisew ${ }^{2}$ \\ ${ }^{1}$ Department of Biology, Mizan Tepi-University, Tepi, Ethiopia \\ ${ }^{2}$ Department of Biology, Bahir Dar University, Bahir Dar, Ethiopia \\ Correspondence should be addressed to Tayachew Admas; tayeadmas2009@gmail.com
}

Received 3 July 2021; Revised 5 January 2022; Accepted 28 January 2022; Published 15 February 2022

Academic Editor: Sylvester C. Chima

Copyright (c) 2022 Tayachew Admas and Bizuayehu Kerisew. This is an open access article distributed under the Creative Commons Attribution License, which permits unrestricted use, distribution, and reproduction in any medium, provided the original work is properly cited.

\begin{abstract}
Tannery effluent plays a significant role in increasing pollution in the environment; in particular, it contains toxic heavy metals which cause toxic effects on plant genetic materials. Among tannery effluent chemicals, chromium and lead have cytotoxicity and genotoxicity potentials on Allium cepa. This investigation was undertaken to assess the physicochemical properties of tannery wastewater and their effect on the genetic materials of $A$. cepa. Effluent's physicochemical characteristics were investigated using digital instruments for direct measurement and standard methods of atomic absorption spectrophotometer colorimetric analysis. A series of six onion bulbs were grown in $0 \%, 20 \%, 40 \%, 60 \%, 80 \%$, and $100 \%$ concentrations of wastewater (v/v) ratio, and root tips from each onion bulb were cut and processed for analysis by aceto-orcein squash technique. Most of effluent components were above the discharge limit standards set by Federal Environmental Protection Agency and Ethiopian Environmental Protection Authority. The cytotoxicity effect on the root growth showed a significant reduction at high concentration. Simple regression analysis showed that the results of mitotic index were statistically significant $(P<0.05)$ in different concentrations. A decrease in mitotic index with increasing concentration of the effluent was observed. The effluent had induced chromosomal abnormalities such as laggard, fragmentation, stickiness, bridge, micronucleus, and binucleated and morphologically changed nuclei in A. cepa root cells among others. The results showed that cytotoxicity, genotoxicity, and chromosomal aberrations were induced by the tannery effluent. Industries shall think of biological waste treatment methods.
\end{abstract}

\section{Background}

Expansion of industrialization has a significant role in the developing countries. However, the treatment mechanism of wastewater has a global concern due to the need of high cost of treatment equipment [1]. Therefore, discharging of untreated and partially treated effluent into the environment directly or indirectly affects humans and other life forms $[2,3]$. Indeed, untreated industrial effluent has an effect on the aquatic and terrestrial environments [4]. Industrial wastewater can raise the pollution of surface water and results in great problematic issues to living things' health $[5,6]$. Similar to other developing countries, Ethiopia has a rapid expansion of industries in the urban area. Around 90\% of Ethiopian industries have discharged their effluent without any treatment and this is the primary cause of environmental pollution [7].

Industrial wastes contain heavy metals, organic matter, and nitrogen and are released into the environment with no pretreatment. All these chemicals are received by the water bodies and disturb life forms [8]. Some chemicals like heavy metals have a potential cytotoxicity and genotoxicity effect [9]. Among industries in the tannery effluents, heavy metal (chromium) has a potential to cause cytotoxicity and genotoxicity effects $[10,11]$. A study showed that chromium contained in tannery effluents induced root growth, mitotic index, and chromosomal abnormalities in plant cells (Allium сера) [3]. Therefore, the tanner effluents which are discharged into the environment contain high levels of chemical demand, biological oxygen demand, electrical 
conductivity, and heavy metals; specifically, heavy metals (chromium) beyond tolerable limits have a potential to cause toxicity [12]. The examination of genotoxicity and cytotoxicity effect draw a special attention to the fact that toxic chemicals have ability to induce the formation of tumor in examined organism and cause humans exposed to toxic chemicals directly or indirectly [13]. Among plants, the best species $A$. cepa $(2 n=16)$ bioassay is used for in situ environmental monitoring, especially water quality assessment [14]. Nowadays, Ethiopia has strategies to implement Agricultural Development Lead Industrialization (ADLI). In this respect, the country needs to plan an effective management system of effluents which are discharged from industries. Otherwise, biota and human beings will be affected by those industrial effluents which contain a complex toxic chemical. Regardless of the presence of ample evidence for the presence of mutagenic components in industrial effluents characterized from Ethiopia, there is no work done regarding the degree of toxicity of industrial effluents on cells, genes, and DNA.

\section{Materials and Methods}

2.1. Study Area. This study was conducted at Bahir Dar tannery which is situated in Bahir Dar town, the capital city of Amhara National Regional State of Ethiopia [15]. Bahir Dar tannery is found in Kebele 07; their wastewater is directly discharged into Blue Nile River and has a lot of problems on living things that make direct contact with toxic chemicals present in the wastewaters.

2.2. Study Design. The study was carried out by using an experimental study to examine the cytotoxicity, genotoxicity, and chromosomal aberrations of tannery effluent on A. cepa root tip. A. cepa was a plant used as an indicator or a model organism in this study to generate the primary data.

\subsection{Selection Criteria of Sampling Site and Sampling} Technique. The sampling site was selected based on prior knowledge about the tannery effluent containing many toxic chemicals compared to other industries in the town. In addition to this, Bahir Dar tannery (from where the effluent was collected) directly discharges the effluent into Blue Nile River. Sample was collected using a spot sample technique where a single sample was taken from the outlet of the effluent for analysis.

2.4. Experimental Organism or Plant Material. Healthy and equal sized bulb onions ( $A$. cepa L.: $2 n=16$ ) were purchased from Bahir Dar Market. The onions were dried out in the sun for two weeks to remove old grown roots and the dried bulbs were later used for tests to check the toxicity effect of effluent [16].

\subsection{Experimental Procedures}

2.5.1. Physicochemical Test. The tannery effluent was obtained in Bahir Dar city. The effluent samples were collected before their discharge into the coastal water.
The collected tannery effluent samples were characterized for their physical and chemical parameters like temperature, $\mathrm{pH}$, conductivity, and turbidity; biological oxygen demand, phosphorus, sulfide, total dissolved solids, and total suspended solid standards were studied [17]. Selectively, some heavy toxic metals like chromium, lead, zinc, and phosphorus sulfide present in the tannery effluent were checked using atomic absorption spectrophotometer (AAS) at Amhara Design and Supervision Works Enterprise Laboratory Service.

2.5.2. Heavy Metal Analysis. To determine the heavy metals in the water sample, we used the following steps at Amhara Design and Supervision Works Enterprise laboratory service. According to Srikanth et al. [18], first $100 \mathrm{ml}$ water sample was added to the digestion flask. Next, $3 \mathrm{ml}$ of concentrated $\mathrm{HNO}_{3}$ acid was added and then digested at $120^{\circ} \mathrm{C}$ for 1 hour. Then the sample was cooled down for 5 minutes and again $3 \mathrm{ml}$ of $\mathrm{HNO}_{3}$ acid was added and digested at $180^{\circ} \mathrm{C}$ for 40 minutes. After that, the sample was cooled for 5 minutes and $10 \mathrm{ml}$ of concentrated $\mathrm{HCl}$ acid was added and digested at $240^{\circ} \mathrm{C}$ for 20 minutes. Finally, the digested sample was filtered by Whatman No. 2 in a $100 \mathrm{ml}$ volumetric flask. After that, $10 \mathrm{ml}$ of the digested sample was added in the test tube and then heavy metals like chromium, lead, and zinc were determined by using atomic absorption spectrophotometer (AAS). The result was expressed in $\mathrm{mg} / \mathrm{L}$ or ppm.

2.5.3. Colorimetric Analysis. It was also done at Amhara Design and Supervision Work Enterprise laboratory service using the following steps. According to Srikanth et al. [18], first $10 \mathrm{ml}$ of water sample was added to the Palintest tube. Next, sulfide 1 tablet was added and crushed for dissolving and sulfide 2 tablet was added and crushed for full dissolving to sulphur and phosphate was used in place of sulfide for phosphorus. Then we waited 10 minutes for full color developing. Finally, Photos 33 and 29 were selected for reading for sulphur and phosphorus, respectively, and the result was expressed in $\mathrm{mg} / \mathrm{L}$ or $\mathrm{ppm}$.

2.5.4. Planting of Onion. The outer scales of the bulbs and the brownish bottom plate were first removed. The rings of the root primordia were not being damaged. A series of cleaned small sized bulbs of onions (Allium cepa) were first grown in water as described by Fiskesjö [19]. Onion bulbs were germinated primarily in plastic bottles and glass jar and filled with normal water for 24 hours. After germination, the best in terms of root growth were selected for tests. Six onions were selected; each onion was placed on the top of containers filled with different concentrations (20\%, 40\%, $60 \%, 80 \%$, and $100 \%$ ) of tannery effluent for 5 days in three replicates and tap water was used as a positive control. The solutions were changed every day during the experiment.

2.5.5. Root Growth Inhibition Test. The root lengths of onion bulbs from each different concentration were measured on 
days 2, 3, and 4 of the experiment using a meter ruler. According to the report by Babatunde and Anabuike [20], the root growth inhibition percentages were calculated by using the following formula:

root growth inhibition $(\%)=$ control group root growth $(\%)-$ concentration root growth $(\%)$.

2.5.6. Root Tip Preparation for Analysis. The emerged root tips of the onion bulbs in different concentration of tannery effluent were fixed in ethanol glacial acetic acid $(3: 1)$ after the second and fourth days of starting the experiment. The conventional Feulgen-squash method [21] was used to prepare permanent slides of root meristem cells.

The root tips were put in $1 \mathrm{~N} \mathrm{HCL}$ at $60^{\circ} \mathrm{C}$ for five minutes to soften the tissue. The tips were macerated and stained with Aceto-orcein stain for 10 minutes. The tip of the root was then cut with a sharp blade and placed on a glass slide and covered with a cover slip carefully [22].
The macerated and stained root tips were covered with a cover slip and squashed and later viewed in a microscope. The prepared slides were observed under microscope to evaluate different stages of mitosis and mitotic index; mitotic inhibition was calculated. Each experiment was repeated three times, and at least three slides were prepared for each parameter. The slides were scored for mitotic index and chromosomal aberrations in Olympus DP73 fluorescent microscope (cell count at 40X and aberration photos taken at $100 \mathrm{X})$ with an attached image analyzer.

According to Sehgal et al. [23], the mitotic index can be recorded using the formula:

$$
\text { mitotic index }=\frac{\text { dividing cell in all phase }}{\text { total number of cell }} \times 100 \text {. }
$$

According to Fiskesjó [22], mitotic inhibition can be calculated as

$$
\text { mitotic inhibitiom }=\frac{\text { mitotic index in the control group }- \text { mitotic index in the test group }}{\text { mitotic index in the control }} \times 100 \text {. }
$$

The mitotic activity (analyzed for cytotoxicity effect), by looking at the morphological changes in the nuclei during cell division (for genotoxicity effect) and structural chromosomal aberration in different concentrations of tannery effluent, was recorded in different stages of mitosis. Micrographs of all the above effects were taken.

2.6. Data Analysis. Statistical analyses were performed by using Microsoft Office Excel 2007 and SPSS version 20 software package programs. Data on physicochemical parameters were represented by mean \pm SE in tables. The mean root length of each treatment in each concentration was calculated by dividing the total root length for each concentration by the replications. The root length of the control was also calculated and the result changed in percentages and was plotted on a graph.

The data of root length and mitotic index (MI) were represented in mean $\pm \mathrm{SE}$ of three scores in each different concentration. The percentages of root growth, mitotic index, and mitotic inhibition were calculated and plotted using a simple bar graph and line graph. The results of root growth, mitotic index, and concentration were statistically evaluated at $5 \%$ significance level to confirm the variability of the data and the validity of results. Differences between corresponding control and exposure treatments were considered statistically significant at $P<0.05$.

The genotoxicity and chromosomal aberrations (CA) of the results were represented by using micrographs taken using Olympus DP73 fluorescent microscope for each phase of mitosis.

\section{Results}

3.1. Physicochemical Parameter Test. In the present study, most of the physicochemical parameters listed (Table 1) were above the discharge limit set by FEPA and EEPA of the effluent. Among the chemicals analyzed in this study, chromium and lead were present in high amount in the effluent, $2.54 \mathrm{mg} / \mathrm{L}$ and $2.13 \mathrm{mg} / \mathrm{L}$, respectively (shown in Table 2). These chemicals were toxic and had a negative effect on Allium cepa genetic material.

3.2. Root Number and Inhibition Test. The root growth of effluent concentration was significantly different from the control as determined by a simple regression test $(P<0.05)$ as shown in Figure 1.

During the experiment, the root tips of onions cultivated in $40 \%, 60 \%, 80 \%$, and $100 \%$ turned into greenish brown 
TABle 1: Physicochemical characteristics of Bahir Dar tannery effluent after treatment.

\begin{tabular}{lccc}
\hline Checked parameters for physicochemical analysis & Present study (mean \pm SE) & Literature value (mean \pm SE) & $\begin{array}{r}\text { Discharge limit } \\
\text { FEPA }\end{array}$ \\
EEPA
\end{tabular}

All values are mean of triplicates \pm SE.

TABLE 2: The concentrations of some chemicals that were revealed in the tannery effluent.

\begin{tabular}{lcccc}
\hline Chemicals $(\mathrm{mg} / \mathrm{l})$ & Present study values $(\mathrm{mg} / \mathrm{l})$ & Literature values $(\mathrm{mg} / \mathrm{l})$ & References & EEPA standard $(\mathrm{mg} / \mathrm{l})$ \\
\hline Lead $(\mathrm{Pb})$ & 2.13 & - & {$[24]$} & 2.00 \\
Chromium $(\mathrm{Cr})$ & 2.54 & 3.54 & & 2.00 \\
Zinc $(\mathrm{Zn})$ & 0.018 & - & {$[24]$} & - \\
Phosphorus $(\mathrm{P})$ & 26 & 11.5 & {$[24]$} & 10 \\
Sulfides $(\mathrm{S})$ & 65 & 16.05 & 1.00 \\
\hline
\end{tabular}

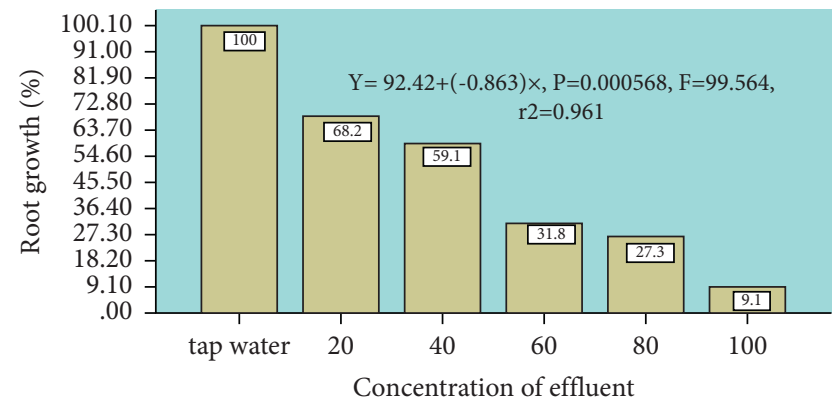

Figure 1: Root growth (\%) of A. cepa at different concentrations of tannery effluent with 24-hour exposure. The root growth of effluent concentration was significantly different from the control as determined by a simple regression test $(P<0.05)$.

color. This was observed on days 3 (Figure 2) and 4 (Figure 3 ), and the change in root tip color was most intense in onions cultivated in $60 \%-100 \%$ concentration. The root morphology in different concentrations was nearly normal during the first day of germination and became fatter, blunt, and shorter after the second day, compared to the positive control. On the third day (72 hours) of planting, Allium cepa root length in the control group was $3.8 \pm 0.75$ and roots grown in $100 \%$ tannery effluent had a length of $0.1 \pm 0.00$.

3.3. Cytotoxicity Test. In this study, the highest number $(613 \pm 3.46)$ of dividing cells was observed in the control group and the least $(165.33 \pm 25.40)$ in the $100 \%$ effluent concentration (Table 3). The mitotic index decreased as the concentration of the effluent increased, while in Figure 4, the mitotic inhibition increased with concentration, with the $100 \%$ concentration showing $73.09 \%$ mitotic inhibition, whereas there was a major reduction at the $20 \%$ concentration which only inhibited mitosis to $9.53 \%$ (Figure 5). There was an inverse relationship between the mitotic index

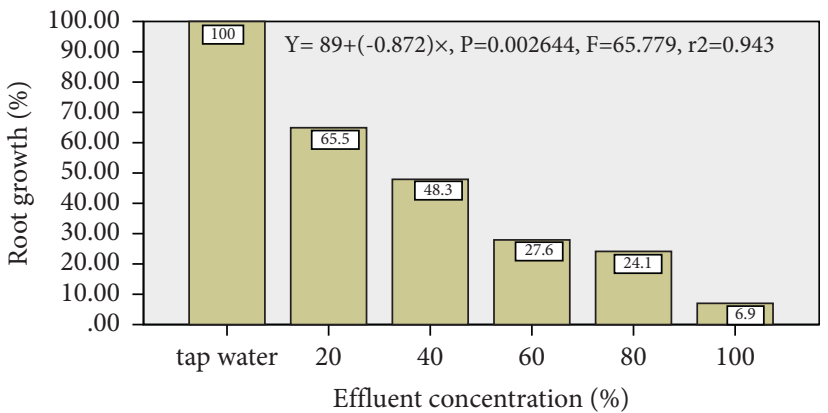

Figure 2: Root growth (\%) of A. cepa at different concentrations of tannery effluent with 48-hour exposure. The root growth of tannery effluent concentration was significantly different from the control as determined by a simple regression test $(P<0.05)$.

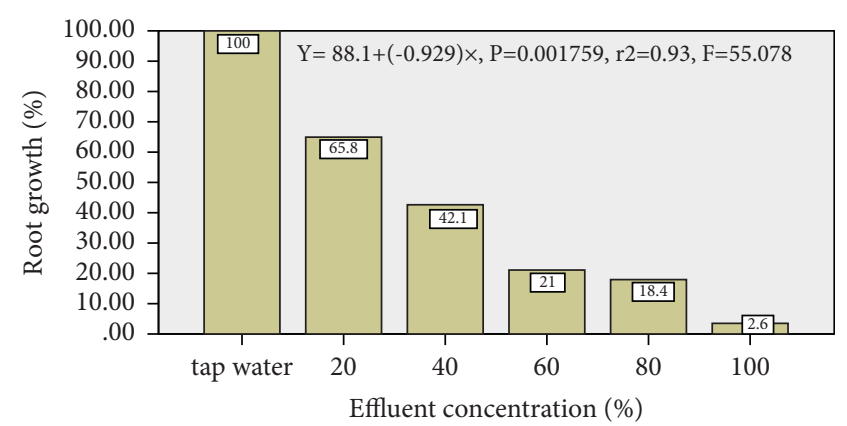

Figure 3: Root growth (\%) of Allium cepa in different concentrations of tannery effluent with 72-hour exposure. The root growth of tannery concentration was significantly different from the control as determined by a simple regression test $(P<0.05)$.

and the mitotic inhibition such that as the concentration increased, the mitotic index decreased, whereas the mitotic inhibition increased. In the present study, the mitotic index 
TABLE 3: Average number of cells and dividing cells of $A$. cepa roots per slide in three replicated slides for each concentration and cytological effect of tannery effluent on $A$. cepa cells.

\begin{tabular}{lcccc}
\hline Treatment concentrations (\%) & Total number of cells & Dividing cells & Mitotic index (\%) & Mitotic inhibition (\%) \\
\hline Control group & $6625.66 \pm 257.9$ & $613 \pm 3.46$ & 9.55 & 0 \\
20 & $6480.33 \pm 90.17$ & $555 \pm 27.61$ & 8.64 & 9.53 \\
40 & $6413.66 \pm 69.57$ & $477.33 \pm 18.48$ & 7.43 & 22.18 \\
60 & $6433.33 \pm 122.38$ & $337.66 \pm 6.69$ & 5.23 & 45.23 \\
80 & $6441.33 \pm 251.59$ & $247 \pm 19.35$ & 3.85 & 59.68 \\
100 & $6129.66 \pm 136.46$ & $165.33 \pm 25.40$ & 2.57 & 73.09 \\
\hline
\end{tabular}

Note: mitotic index had a significantly negative relationship with tannery effluent concentration percentage at $P=0.00005988$ and $r^{2}=0.9873$ checked with simple linear regression analysis; increase of tannery concentrations $(P<0.05)$.

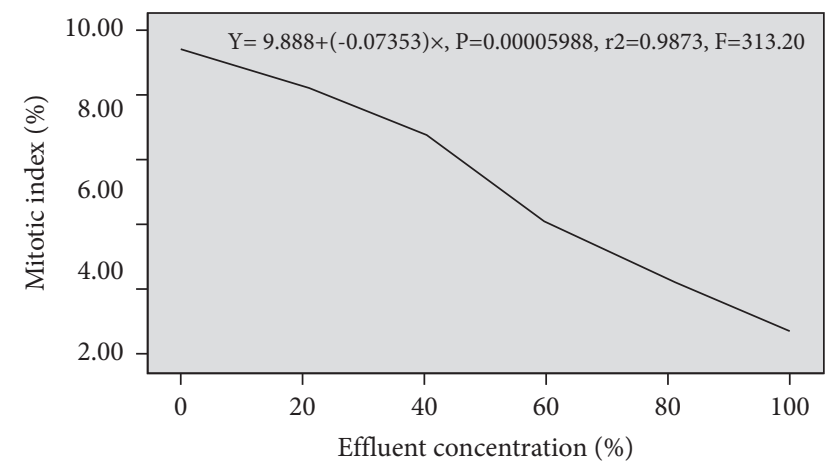

Figure 4: Mitotic index (\%) of root cells of A. cepa following treatment with different concentrations of tannery effluent.

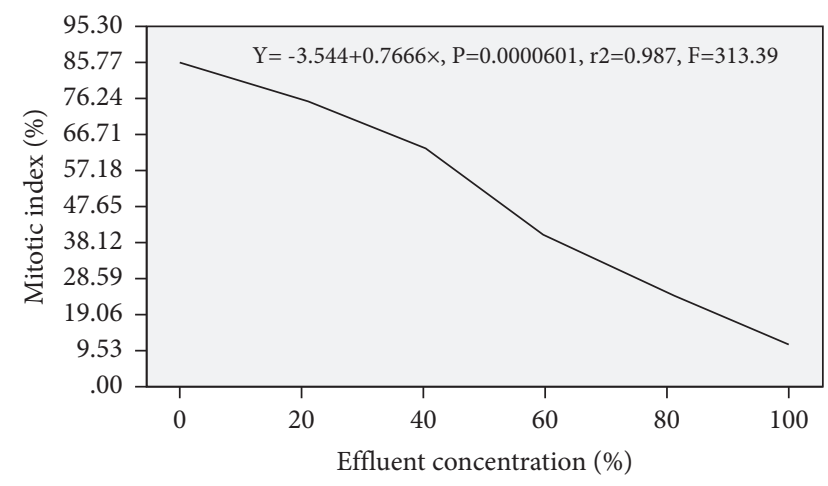

Figure 5: Mitotic inhibition (\%) of root cells of $A$. cepa following treatment with different concentrations of tannery effluent.

values showed a significant reduction with the increase of tannery concentrations $(P<0.05)$.

\subsection{Genotoxicity Test}

3.4.1. Chromosomal Aberrations. In this study (as shown in Figure 6), there were no chromosomal aberrations or nuclear abnormalities observed in the stages of mitosis in the positive controls which were grown in tap water. All prophase, metaphase, anaphase, and telophase stages were clearly visible with normal position without any chromosomal alterations.

Unlike in the control group, chromosomal abnormalities were observed at the mitotic stages of prophase, metaphase, anaphase, and telophase of $A$. cepa root cells grown with different concentrations of tannery effluent (as shown in Figure 7). When the duration of time was increased, a proportional increase of the degree of chromosomal abnormalities was also observed in this study.

3.4.2. Nuclear Abnormalities. In the current study, different types of nuclear abnormalities were also observed, including cells membrane, fragmented nuclei, binucleated cells, and micronucleus formation. Moreover, the shape and size of cellular alterations were observed (extended cells) (Figure 8). An abnormality of nuclei in the cell clearly indicates that something becomes wrong in the cell; this may be due to the effects of heavy metals present in the tannery effluent. It indicated that genetic materials like DNA were easily altered. However, there were no nuclear abnormalities observed in the control group.

\section{Discussion}

In the current study, the tannery wastewater showed a significant effect on the physicochemical parameters of fresh water and it can disturb all life forms, due to the change in electrical conductivity, turbidity, total dissolved solids, total suspended solids, biological oxygen demand chromium, lead, sulfide, and phosphorus. Except electrical conductivity, all parameters were found to be higher than the discharge limits of FEPA and EEPA standard deviation in number from a report by Assefa and Ayalew [24]. This is due to the production and processing capacity of the tannery industry during the sample collection time. Similar results were revealed by Dadi et al. [25]; effluents with concentrations above the legally permissible limits are likely to degrade and destroy local environments directly and indirectly by affecting the physical and biological environment, such as land, water, and living organisms and human beings.

For the disposal of such type of tannery wastewater, it is not safe to discharge it into water bodies without proper treatment because it alters the physicochemical properties of the water and creates a high risk facing deleterious health effects even if present at low concentration [26].

Heavy metals have a negative effect on plant genetic material; among those metals, chromium is well known to be toxic to living organisms due to its bioaccumulation and nonbiodegradable properties. In this study, a chromium concentration above the permissible limit was recorded and a similar result was reported by Assefa and Ayalew [24]. 


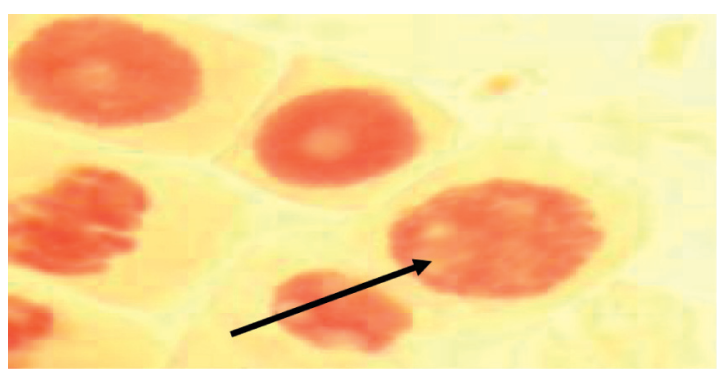

(a)

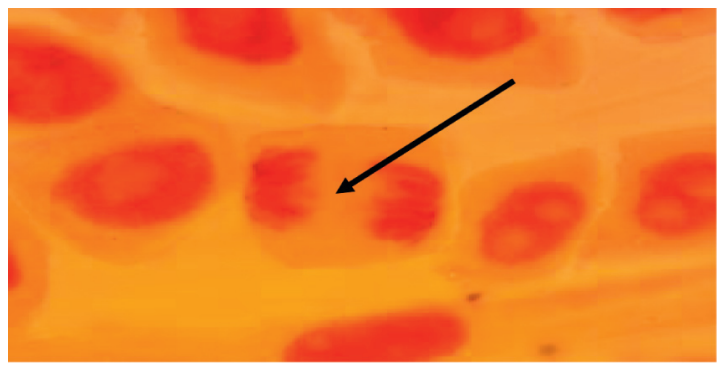

(c)

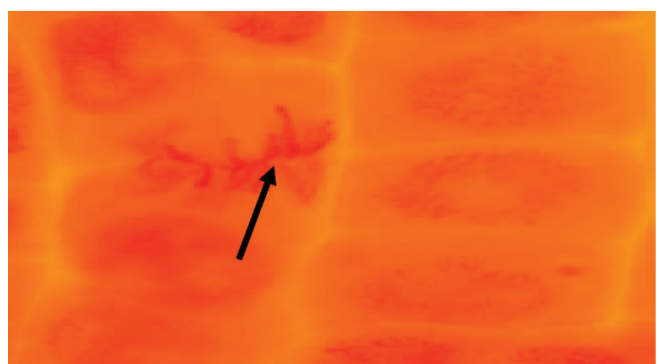

(b)

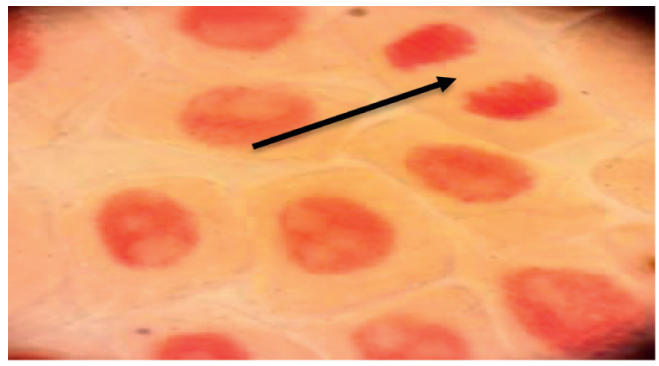

(d)

Figure 6: Allium cepa root tip cells grown as a control group (tap water): (a) prophase with visible chromosomes; (b) metaphase chromosomes at the equator plate; (c) anaphase, chromosomes move to the opposite pole; (d) telophase, chromosomes following cytokinesis.

Similar result was reported by Najeeb et al. [27]. In China, lead is also a toxic heavy metal that disturbs various plant physiological processes. A plant with high lead concentration suppresses the overall growth of the plant.

The cell toxicity effect of tannery wastewater is assessed by root growth inhibition effect and changes in mitotic index data [20]. In this regard, our study showed that Allium cepa root growth depended on the tannery effluent concentration. Root growth and tannery effluent concentrations were inversely related. When the concentration of effluent increases, the growth ability of roots is reduced. This result agreed with the report of Ukaegbu and Odeigah [28] in Nigeria.

The reduction in root growth is indicator of halt of mitotic cell division [29]. Similarly, root growth inhibition occurs as a result of the inhibition of cell division (indicating cytotoxicity) and it is thus an index for estimating general toxicity. It occurs when roots are exposed to a wrong $\mathrm{pH}$ or to unsolved substances that may prevent nutrition uptake [22].

One of the heavy metals recorded above the permissible limit in this study was lead. It has been known to cause reduction in root growth and the frequency of mitotic cells in the meristematic zone of onions. It also induces chromosome damage and its disturbance of mitotic processes in onions [30]. This supports our result of clear defects of mitotic cell division phase in A. cepa root cells caused by tannery effluents.

Increase or decrease in mitotic index is an important indicator in environmental monitoring and for the evaluation of toxic substances that have cytotoxic potential [31]. Mitotic index is considered as an acceptable measure of cytotoxicity for all living organisms [32] and it is considered as a parameter that allows estimating the frequency of cell division [14].

In this study, the mitotic index was decreased with increased tannery concentration; this result is in agreement with the previous work carried out by Panda [33], Kwankura [34], and Olorunfemi et al. [35]. Mitotic index alterations can indicate changes derived from chemical action in the growth and development of exposed organisms [14].

The exposure to heavy metals prevents plant cells from entering the cell division phase and leads to a decrease in the mitotic index. The primary action of heavy metals on the mitotic spindle promoted spindle related chromosomal abnormalities during cell division [36] and all these have been clearly observed in our results.

The reduced mitotic index compared to the control in our study suggests that the cells have an inhibitory effect on the biosynthesis of DNA. This restricts the synthesized DNA entering the next stage of the cell cycle, which is the second gap stage. It is after this stage that the cell can enter mitosis and this is supported by a report of a previous study by Ping et al. [37]. Therefore, the decrease of the mitotic index with the increase in the concentration of the effluent indicates that high concentration of tannery effluents inhibits cell proliferation.

In this study, chromosomal abnormalities were observed in different mitotic stages. This is in agreement with observations in the earlier related studies by Olorunfemi et al. [38]. Chromosomal bridges and stickiness were the most frequent abnormalities detected in the tannery effluent grown root tips of $A$. cepa cells. However, chromosomal bridges and stickiness were commonly observed in anaphase and metaphase stages, respectively. The metaphase stickiness 


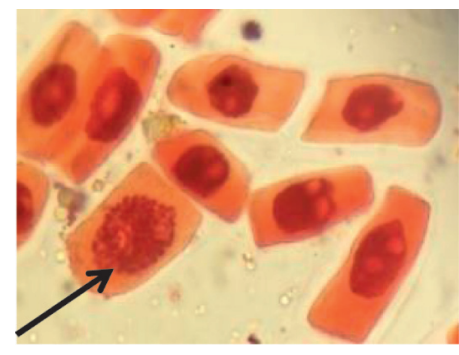

(a)

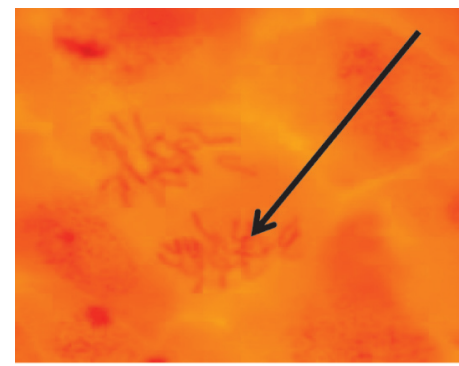

(d)

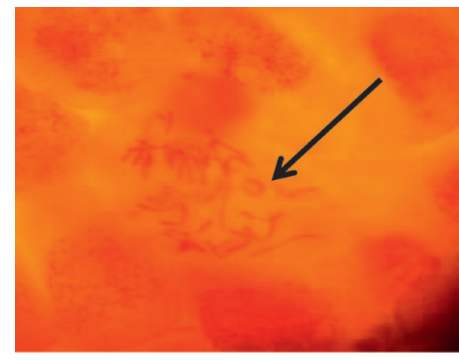

(g)

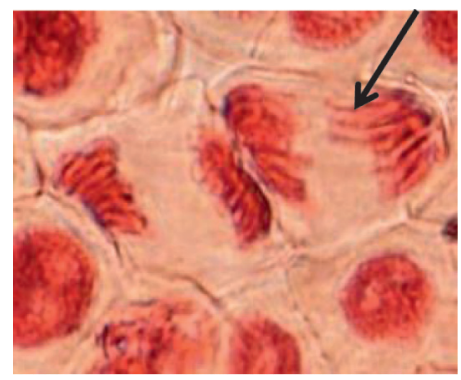

(j)

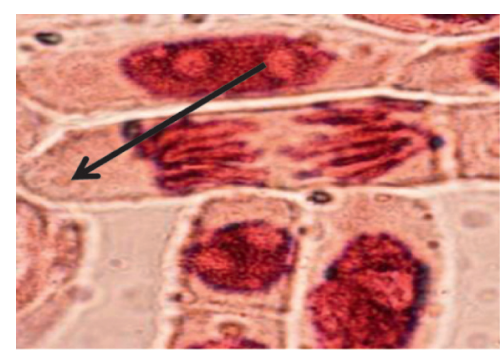

(b)

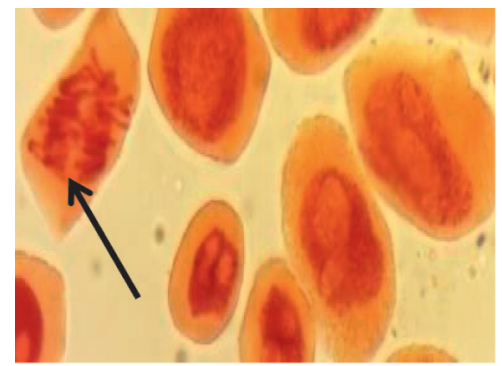

(e)

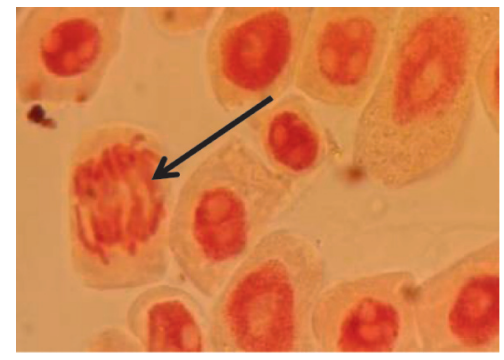

(h)

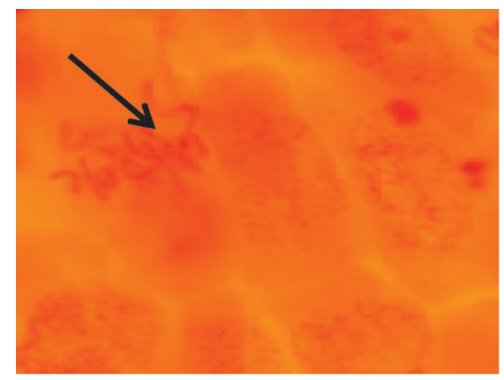

(k)

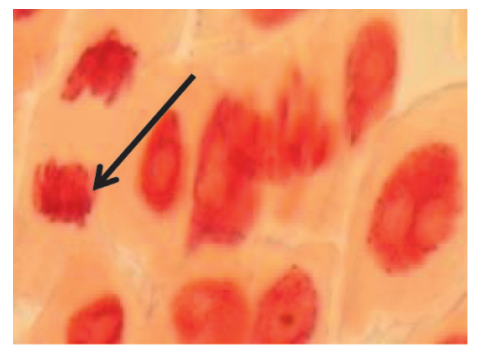

(c)

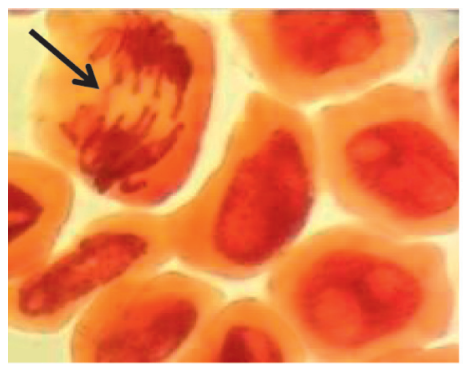

(f)

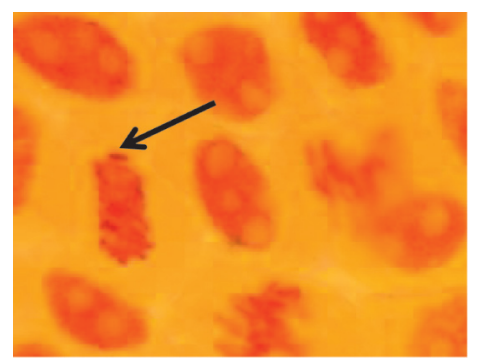

(i)

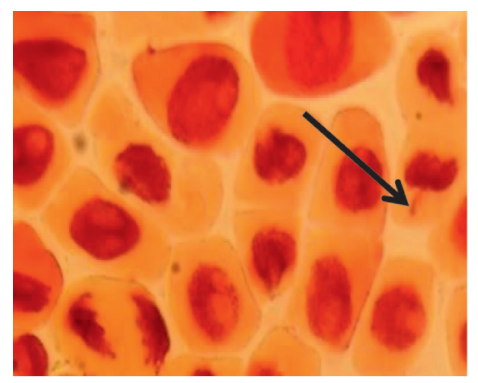

(l)

Figure 7: Allium cepa root tip cells grown in tannery effluent. (a) Sticky chromosomes at prophase, chromosomes were not clearly visible; (b) polar slip; (c) sticky anaphase; (d) disturbed and fragmented anaphase; (e) delayed anaphase; (f) single chromosomal bridge anaphase; (g) chromosome missegregation and fragmentation; (h) multiple chromosomal bridges at anaphase; (i) chromosomal breakage; (j) lagging chromosome; (k) irregular metaphase; (l) telophase with vagrant chromosome.

in this study corresponds to a research done by Firbas and Amon [39].

Previous studies have tried to relate the causes for these chromosomal aberrations. The trace elements recorded as above the permissible limit in this study have been mentioned repeatedly as potential mutagens supporting our results. Lerda [30] and Walker et al. [40] pointed out that the most frequent chromosome aberration in chromium is stickiness and chromosome break, for lead chromosome break, chromosome loss, and lobulated nuclei and zinc were related to stickiness and multipolarity. It is reported that aberrations such as breaks and fragments are induced due to the formation of DNA-DNA and DNA-protein cross-links and heavy metals are considered as a major contributor in this regard. Tannery effluent contains several heavy metals, especially chromium, which is cytotoxic and inhibits cell division in the root tips of plants [41].

Most of the aberrations in the current study were sticky at metaphase and the chromosomes were condensed at the equatorial plate. Similar reports were given by Soodan et al. [42], Olorunfemi et al. [38], and Ogunyemi et al. [43]. In this study, the opposite poles of chromatids were tightly linked to 


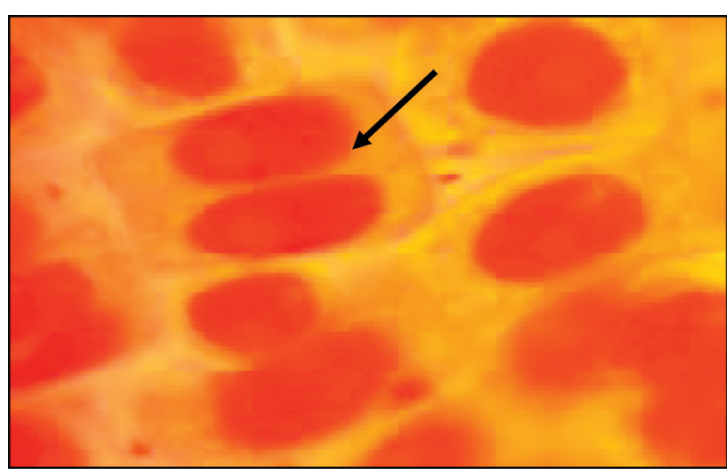

(a)

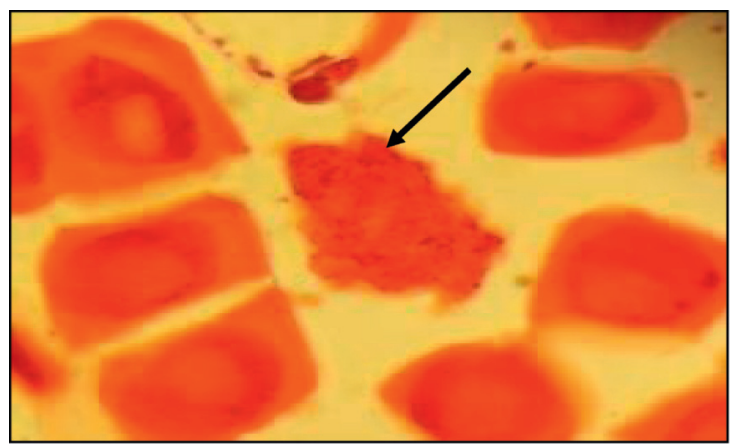

(c)

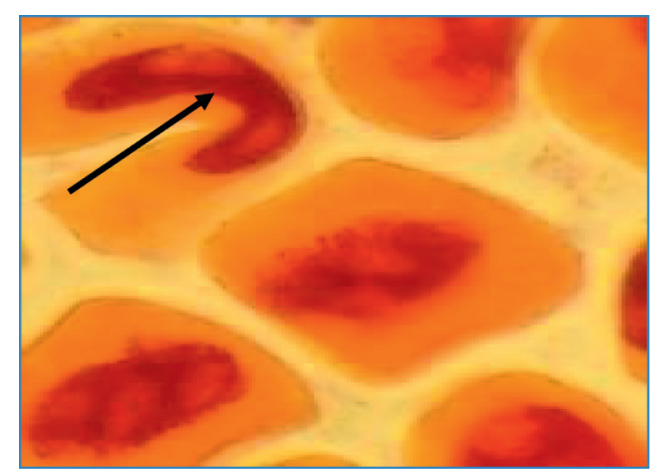

(b)

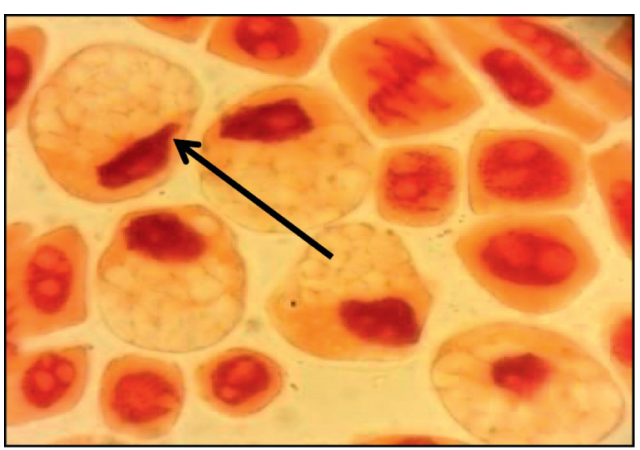

(d)

Figure 8: Allium cepa root cells indicate genotoxicity of tannery effluent by the morphological structure of nuclei. (a) Binucleated cells, (b) lobulated nuclei, (c) cells with damaged membrane, and (d) morphologically damaged cells in shape and size.

each other during anaphase forming chromosome bridges resulting from adherence and may persist until telophase. This was also observed in anaphase stages reported by Soodan et al. [42], Olorunfemi et al. [38], and Ogunyemi et al. [43].

Delayed anaphase was also seen as a result of the mutagenic effect of the tannery effluent. In this study, the two anaphasic chromosomal groups were close to each other near the equatorial plate. They were not fully separated and moved towards opposite poles. This aberration was also similar to the result reported by Soodan et al. [42]. The lagging chromosomes resulted due to failure of the chromosomes to get attached to the spindle fiber and to move to either of the two poles; similar results were observed by Ogunyemi et al. [43] and Nefic et al. [44].

Another result observed in this study was the morphological change of the nucleus which is used to predict genotoxicity along with chromosomal abnormalities [14]. Micronucleus has been measured as the most powerful and easy to check the mutagenic effect of chemicals [45]. Similar to the current study result, the micronucleus was reported as composed of either small chromatin fragments, which arise as a result of chromosomal breakage, or whole chromosomes that do not migrate during anaphase as a result of spindle dysfunction [14]. All these alterations in the morphology of nuclei in the cell indicated that tannery effluent has a toxic effect on the gene of the model plant (Allium cepa) and this can be used as a genotoxicity measurement. These nucleus changes in the micronucleated cells were observed in studies reported by Ogunyemi et al. [43] and Nefic et al. [44]. The presence of micronucleated cells indicates an aneugenic and clastogenic activity, because, according to Fenech [46], micronucleus can be derived from acentric fragments, which indicates clastogenic activity, or from entire chromosomes, which indicates an aneugenic activity.

\section{Conclusion}

Results obtained from this study showed that cytotoxicity, genotoxicity, and chromosomal aberrations were induced by the tannery effluent. These results were due to the presence of most of the physicochemical parameters of the effluent above their discharge limit set by FEPA and EEPA. The increase in the physicochemical properties of the tannery wastewater clearly indicates that the effluent is a highly contaminated and toxic substance which has an adverse effect on life and the environment. This study used the A. cepa bioassay with different toxicity endpoints (root growth, mitotic index, and occurrence of micronuclei, nuclear abnormalities, and chromosomal aberrations) to assess the potential of toxicity of tannery wastewater and the bioassay revealed that the tannery effluent consistently contained cytogenotoxic contaminations over the study period. The results of this study indicated that the cytotoxic effect of A. cepa depends on tannery effluent concentration; even low doses demonstrate a considerable rate of inhibition in root growth rate. Moreover, the destructive effects of tannery effluent on the mitotic index of $A$. cepa cells show 
that it has a cytotoxic effect on root tip cells. The genotoxicity and structural chromosomal aberrations were also observed in $A$. cepa root cells, which were grown by tannery effluent. Aberrations can originate due to the development of the isolated chromosome that results from an unequal distribution of genetic material due to the effect of the effluent components. However, their induction is commonly used to detect genetic damage derived from exposure to mutagenic chemicals. The abnormalities may be due to the presence of heavy metals in the effluent and it has toxic effects on the genetic material of the living organisms. It is thus concluded that the tannery effluent used in this study has mutagenic components that are toxic to cells (life). In addition, the model plant assay used in the current study's ( $A$. cepa) test is an easy, fast, and very sensitive assay to detect the environmental genotoxicity of chemicals. This assay is related to studying the effect of chemicals at the genetic level.

\section{Data Availability}

The data used and analyzed during the current study are available from the corresponding author upon request.

\section{Conflicts of Interest}

The authors declare that they have no conflicts of interest.

\section{Authors' Contributions}

TA contributed to the conception or design of the work; the acquisition, analysis, and interpretation of data for the work; drafting the work and revising it critically for important intellectual content; and final approval of the version to be published (agreement to be accountable for all aspects of any part of the work is appropriately investigated and resolved). BK contributed to conceptual design, drafting the work and revising it critically for important intellectual content analysis and interpretation, and writing work draft and revising requests of manuscript.

\section{Acknowledgments}

The authors would like to thank Bahir Dar University's Biology Department staff members. The authors also acknowledge Bahir Dar University's webcite https://ir.bdu. edu.et/handle//123456789/9644 for addressing the full thesis version of the article.

\section{References}

[1] S. K.. Arjun, S. Kumar, Y. Kumar, and H. C. Sharma, "Effect of fertilizer factory effluent on wheat crop: a case study," Access International Journal, vol. 1, no. 7, pp. 81-90, 2013.

[2] A. A. Bakare, A. A. Okunola, O. A. Adetunji, and H. B. Jenmi, "Genotoxicity assessment of a pharmaceutical effluent using four bioassays," Genetics and Molecular Biology, vol. 32, no. 2, pp. 373-381, 2009.

[3] D. I. Olournfemi, G. E. Okoloko, A. A. Bakare, and A. Akinboro, "Cytotoxic and genotoxic of effects of cassava effluents using the Allium cepa assay," Research Journal of Mutation, vol. 1, pp. 1994-7917, 2010.
[4] D. I. Olorunfemi, G. E. Okoloko, A. A. Bakare, and A. Akinboro, "Cytotoxic and genotoxic effects of cassava effluents using the Allium cepa assay," Research Journal of Mutagenesis, vol. 1, no. 1, pp. 1-9, 2011.

[5] T. Ohe, P. A. White, and D. M. DeMarini, "Mutagenic characteristics of river waters flowing through large metropolitan areas in North America," Mutation Research: Genetic Toxicology and Environmental Mutagenesis, vol. 534, no. 1-2, pp. 101-112, 2003.

[6] A. Buschini, A. Martino, B. Gustavino et al., "Comet assay and micronucleus test in circulating erythrocytes of Cyprinus carpio specimens exposed in situ to lake waters treated with disinfectants for potabilization," Mutation Research: Genetic Toxicology and Environmental Mutagenesis, vol. 557, no. 2, pp. 119-129, 2004.

[7] S. Melaku, T. Wondimu, R. Dams, and L. Moens, "Simultaneous determination of trace elements in tinishu akaki river water sample, Ethiopia, by icpms," Canadian Journal of Analytical Sciences and Spectroscopy, vol. 49, no. 6, pp. 374384, 2004.

[8] S. Leta, "Developing and optimizing process for biological nitrogen removal from tannery wastewaters in Ethiopia," Doctoral dissertation, Department of Biotechnology, Royal Institute of Technology, Stockholm, Sweden, 2004.

[9] L. D. Claxton, V. S. Houk, and T. J. Hughes, "Genotoxicity of industrial wastes and effluents," Mutation Research: Reviews in Mutation Research, vol. 410, no. 3, pp. 237-243, 1998.

[10] S. Chandra, L. K. S. Chauhan, P. N. Pande, and S. K. Gupta, "Cytogenetic effects of leachates from tannery solid waste on the somatic cells ofVicia faba," Environmental Toxicology, vol. 19, no. 2, pp. 129-133, 2004.

[11] S. T. Matsumoto, M. S. Mantovani, M. I. Mallaguti, and M. A. Marin- Morales, "Investigation of the genotoxic potential of the waters of a river receiving tannery effluents by means of the in vitro comet assay," Cytologia, vol. 68, pp. 395-401, 2006.

[12] N. Lal, "Biochemical alterations due to acute tannery effluent toxicity in Lemnaminor L," Journal of Phytology, vol. 1, pp. 361-368, 2009.

[13] M. C. Garcia- Rodriguez, V. Lopez-Santiago, and M. Altamirano-Lo-zano, "Effect of chlorophyllin on chromium triox-ide-induced micronuclei in polychromatic erythrocytes in mouse peripheral blood," Mutation Research, vol. 496, pp. 145-151, 2001.

[14] D. M. Leme and M. A. Marin-Morales, "Allium cepa test in environmental monitoring: a review on its application," Mutation Research: Reviews in Mutation Research, vol. 682, no. 1, pp. 71-81, 2009.

[15] CSA, Federal Democratic Republic of Ethiopia, Central Stastical Agency Survey, Addis Ababa, Ethiopia, 2010.

[16] B. B. Babatunde and A. A. Bakere, "Genotoxicity screening of waste waters from Agbara Industrial Estate, Nigeria, evaluated with the Allium test," Pollution Research, vol. 25, no. 2, pp. 227-234, 2006.

[17] APHA, Standard Methods for the Examination of Water and Waste Water, American Public Health Association, Washington, DC, USA, 19th edition, 1995.

[18] P. Srikanth, S. A. Somasekhar, G. K. Kanthi, and B. K. Raghu, "Analysis of heavy metals by using atomic absorption spectroscopy from the samples taken around Visakhapatnam," International Journal of Environment, Ecology, Family and Urban Studies, vol. 3, no. 1, pp. 127-132, 2013.

[19] G. Fiskesjö, "The Allium test - an alternative in environmental studies: the relative toxicity of metal ions," Mutation Research: 
Fundamental and Molecular Mechanisms of Mutagenesis, vol. 197, no. 2, pp. 243-260, 1988.

[20] B. Babatunde and F. Anabuike, "In vivo cytogenotoxicity of electronic waste leachate from Iloabuchi electronic market, Diobu, Rivers State, Nigeria on Allium cepa," Challenges, vol. 6, no. 1, pp. 173-187, 2015.

[21] N. Khanna and S. Sharma, "Allium cepa root chromosomal aberration assay," A Review: Indian Journal of Pharmaceutical and Biological Research, vol. 1, no. 3, pp. 2320-9267, 2013.

[22] G. Fiskesjó, "Allium test I: a 2-3 day plant test for toxicity assessment by measuring the mean root growth of onions (allium cepa L.)," Environmental Toxicology and Water Quality, vol. 8, no. 4, pp. 461-470, 1993.

[23] R. Sehgal, S. Roy, and V. L. Kumar, "Evaluation of cytotoxic potential of latex of Calotropis procera and Podophyllotoxin in Allum cepa root model," Biocell, vol. 30, no. 1, pp. 9-13, 2006.

[24] W. Assefa and W. Ayalew, "Bahir Dar tannery effluent characterization and its impact on the head of Blue Nile River," African Journal of Environmental Science and Technology, vol. 8, no. 6, pp. 312-318, 2014.

[25] D. Dadi, T. Stellmacher, F. Senbeta, S. Van Passel, and H. Azadi, "Environmental and health impacts of effluents from textile industries in Ethiopia: the case of Gelan and Dukem, Oromia Regional State," Environmental Monitoring and Assessment, vol. 189, no. 1, p. 11, 2017.

[26] B. R. Parveen and D. Singh, "Assessment of physico-chemical properties of tannery waste water and its impact on fresh water quality," International Journalof Current Microbiol. Applied Science, vol. 6, pp. 1879-1887, 2017.

[27] U. Najeeb, W. Ahmad, M. H. Zia, M. Zaffar, and W. Zhou, "Enhancing the lead phytostabilization in wetland plant Juncus effusus L. through somaclonal manipulation and EDTA enrichment," Arabian Journal of Chemistry, vol. 10, pp. 3310-3317, 2014.

[28] M. C. Ukaegbu and P. G. Odeigah, "The genotoxic effect of sewage effluent on Allium cepa," Report and Opinion, vol. 1, no. 6, pp. 36-41, 2009.

[29] P. L. Webster and R. D. MacLeod, "The root apical meristem and its magrin," in Plant Roots- the Hidden Half", Y. Waishel, A. Eshel, and U. Kafkafi, Eds., pp. 51-76, Marcel Dekker, New York, NY, USA, 2nd edition, 1996.

[30] D. Lerda, "The effect of lead on Allium cepa L." Mutation Research Letters, vol. 281, no. 2, pp. 89-92, 1992.

[31] M. M. Hoshina, "Evaluation of the possible contamination of the rivers of the Claro River - rio Claro municipality, belonging to the Corumbatai river basin, by means of mutagenicity tests in Allium cepa," Completion work (Bachelor eLicenciatura - Biological Sciences), p. 52, Universidade Estadual Paulista, Rio Claro/SP, Brazil, 2002.

[32] V. Smaka-Kincl, P. Stegnar, M. Lovka, and M. J. Toman, "The evaluation of waste, surface and ground water quality using the Allium test procedure," Mutation Research: Genetic Toxicology, vol. 368, no. 3-4, pp. 171-179, 1996.

[33] S. K. Panda, S. Mahapatra, and H. K. Patra, "Chromium toxicity and water stress simulation effects in intact senescing leaves of greengram," in Advance in Stress Physiology in Plants, S. K. Panda, Ed., pp. 129-136, Scientific Publisher, Jodhpur, India, 2002.

[34] W. Kwankura, S. Sengsni, P. Muangphra, and N. Euawong, "Screening of plants sensitive to heavy metals using cytotoxic and genotoxic biomarkers," Kasetsart Juornal of Natural Science, vol. 46, pp. 10-23, 2012.
[35] D. Olorunfemi, E. Duru, and F. Okieimen, "Induction of chromosome aberrations in Allium cepa L. root tips on exposure to ballast water," Caryologia, vol. 65, no. 2, pp. 147-151, 2012.

[36] P. Singh, "Toxic effect of chromium on genotoxicity and cytotoxicity by use of Allium cepa L." International Journal of Research in Engineering and Applied Sciences, vol. 5, pp. 1-10, 2015.

[37] K. Yuet Ping, I. Darah, U. K. Yusuf, and C. Yeng, "Genotoxicity of Euphorbia hirta: an Allium cepa assay," Molecules, vol. 17, no. 7, pp. 7782-7791, 2012.

[38] D. I. Olorunfemi, U. M. Ogieseri, and A. Akinboro, "Genotoxicity screening of industrial effluents using onion bulbs (Allium cepa L.)," Journal of Applied Sciences \& Environmental Management, vol. 15, no. 1, pp. 211-216, 2015.

[39] P. Firbas and T. Amon, "Chromosome damage studies in the onion plantAllium cepaL," Caryologia, vol. 67, no. 1 , pp. 25-35, 2014.

[40] C. H. Walker, R. M. Sibly, S. P. Hopkin, and D. B. Peakall, Principal of Ecotoxicology, CRC Press, Boca Raton, FL, USA, 4th edition, 2012.

[41] S. Chandra, L. Chauhan, R. Murthy, P. Saxena, P. Pande, and S. Gupta, "Comparative biomonitoring of leachates from hazardous solid waste of two industries using Allium test," The Science of the Total Environment, vol. 347, no. 1-3, pp. 46-52, 2005.

[42] R. K. Soodan, J. K. Katnoria, and A. Nagpal, "Allium cepa root chromosomal aberration assay: an efficient test system for evaluating genotoxicity of agricultural soil," International Journal of Science and Research, pp. 3-8, 2014.

[43] A. K. Ogunyemi, T. A. Samuel, O. O. Amund, and M. O. Ilori, "Toxicity evaluation of waste effluent from cassava-processing factory in Lagos state, Nigeria using the Allium cepa assay," IFE Journal of Science, vol. 19, no. 2, pp. 369-377, 2017.

[44] H. Nefic, J. Musanovic, A. Metovic, and K. Kurteshi, "Chromosomal and nuclear alterations in root tip cells of Allium cepa L. induced by alprazolam," Medical Archives, vol. 67 , no. 6 , p. $388,2013$.

[45] T.-H. Ma, Z. Xu, C. Xu et al., "The improved Allium/Vicia root tip micronucleus assay for clastogenicity of environmental pollutants," Mutation Research: Environmental Mutagenesis \& Related Subjects, vol. 334, no. 2, pp. 185-195, 1995.

[46] M. Fenech, "Biomarkers of genetic damage for cancer epidemiology," Toxicology, vol. 181-182, pp. 411-416, 2002. 